УДК33.061.066

Andrii Syshchuk,
Ph. D. in Economics, Associate Professor,
Lesya Ukrainka EUNU,
Department of International Economic Relations and Project Management
Lutsk, ORCID ID: 0000-0002-7379-8063

E-mail: asyshchuk@gmail.com

Iryna Panasiuk, student of the Department of International Relations, major in «International Economic Relations»,

Lesya Ukrainka EUNU

Lutsk, ORCID ID: 0000-0001-7097-9996

E-mail: panasiuk.ira123@gmail.com

https://doi.org/10.29038/2411-4014-2020-01-12-21

\title{
HISTORY AND PRACTICE OF TECHNICAL METHODS OF THE INTERNATIONAL CURRENCY MARKET
}

Introduction. Technical analysis is an assessment of the behavior of the international currency market over a period of time. Due to the unpredictability of the dynamics of the international currency market and the possibility of losses from the conducted transactions, the study of technical means becomes of particular importance and relevance. It is the comparative analysis that identifies the advantages and disadvantages of each of the methods in order to further formulate the most profitable trading strategy.

The purpose of the article is a comparative analysis of the technical analysis methods used by analysts in today's international currency market; comparing the selected instruments of each method and determining the most effective ones.

Results. Within the framework of this study three main methods of technical analysis of the international currency market were considered: graphic, method of mathematical approximation and theory of economic cycles. The individual instruments of each of the methods, such as «Japanese candlestick», simple moving average, the moving average convergence divergence (MACD), MACD histogram, Elliott waves, Fibonacci retracement levels are reviewed. A comparative analysis of the selected instruments is carried out on the basis of research of the specificity of each of them. Examples of graphs, indicators and histograms are given. It is identified that the main differences are the complexity of use (ie the use of mathematical computing and computer technology) and the type of strategy (short or long term). Common features of methods of technical analysis of the currency market are: the purpose of the analysis, the object of analysis and the influence of the factor «psychology of people».

Conclusions. It is revealed that one can obtain the most accurate results in predicting the dynamics of currency quotations only by combining several methods simultaneously. Knowing the strengths and weaknesses of different technical analysis tools, you can use them to validate each other's signals. As a result of such tactics, the analyst will get more accurate indicators that will bring him a profit. The prospect of the research is to find the best strategic schemes using a wide range of technical tools for international currency market analysis.

Keywords: foreign exchange market, currency quotes, technical analysis, trading, Elliot waves.

Сищук Андрій, кандидат економічних наук, доцент, Східносвропейський національний університет імені Лесі Українки, кафедра міжнародних економічних відносин та управління проектами, м. Луцьк

Панасюк Ірина студентка факультету «Міжнародних відносин», Східносвропейський національний університет імені Лесі Українки м. Луцьк 


\title{
ІСТОРІЯ І ПРАКТИКА ТЕХНІЧНИХ МЕТОДІВ АНАЛІЗУ МІЖНАРОДНОГО ВАЛЮТНОГО РИНКУ
}

Розглядаються основні методи технічного аналізу міжнародного валютного ринку: графічний, метод математичної апроксимації та теорія економічних циклів. Наведені характеристики окремих інструментів кожного $з$ методів: «японські свічки», звичайне ковзне середнє, сходження/розбіжність ковзних середніх (MACD), гістограма MACD, хвилі Еліота, рівні Фібоначчі. Проведено компаративний аналіз обраних інструментів на основі дослідження специфіки кожного з них. Визначено їхні основні відмінності та спільні ознаки. Виявлено, що лише шляхом комбінування декількох методів одночасно можна отримати найбільш точні результати у передбаченні динаміки котирувань валют.

Ключові слова: валютний ринок, котирування валют, технічний аналіз, трейдинг, хвилі Еліота.

\author{
Сищук Андрей \\ кандидат экономических наук, доцент, \\ Восточноевропейский национальный университет имени Леси Украинский \\ г. Луцк \\ Панасюк Ирина \\ студентка факультета «Международных отношений», \\ Восточноевропейский национальный университет имени Леси Украинки \\ г. Луцк
}

\section{ИСТОРИЯ И ПРАКТИКА ТЕХНИЧЕСКИХ МЕТОДОВ АНАЛИЗА МЕЖДУНАРОДНОГО ВАЛЮТНОГО РЫНКА}

\begin{abstract}
Рассматриваются основные методы технического анализа международного валютного рынка: графический, метод математической аппроксимации и теория экономических циклов. Приведены характеристики отдельных инструментов каждого из методов: «японские свечи», обычное скользящее среднее, схождение/расхождение скользящих средних (MACD), гистограмма MACD, волны Эллиота, уровни Фибоначчи. Проведен компаративный анализ выбранных инструментов на основе исследования специфики каждого из них. Определены их основные отличия и общие признаки. Обнаружено, что только путем комбинирования нескольких методов одновременно можно получить наиболее точные результаты в прогнозе динамики котировок валют.
\end{abstract}

Ключевые слова: валютный рынок, котировки валют, технический анализ, трейдинг, волны Эллиота.

Target setting and its significance. Technical analysis is an assessment of the behavior of the international currency market over a period of time. It can be used to trace the fluctuations in the market price in previous periods, to assess the market situation on the currency market which will be used to build a winning trading strategy.

Globalization and financial market integration processes are becoming increasingly important. To facilitate and accelerate foreign exchange transactions a single financial space is needed, which the Forex market stands for today. However, due to the unpredictability of its dynamics and possible losses from the conducted transactions, the application of technical means is important in currency trading. Against this background, a comparative analysis of the technical methods of the international currency market is necessary to identify their main advantages and disadvantages, and to shape the direction of further research.

Analysis of recent research and publications. Theoretical and practical studies of technical methods of financial market analysis for the last 5 years have been conducted by such domestic scientists as: A. V. Matviichuk, I. I. Strelchenko (application of advance indicators' system), A. V. Sliusar (Elliott wavelet wave identification), O. V. Tyvodar (analysis of moving average and singular decomposition), Ye. I. Bakai, V. V. Kabachii (estimation of different time measurements) and others. The works of O. I. Bereslavska (international calculations), P. A. Shabdyraimov (strategy of behavior in the foreign exchange market), K. K. S. Todorova, O. M. Hostryk (evaluation and analysis of modern trading platforms in the foreign exchange market) are devoted to clarifying the specifics of foreign exchange transactions in international markets. Aung Khant Min, Jake Elliot Drew Barefoot (currency trading system development), Murat Öztürk 
(heuristic-based trading system on Forex data), Jozef Barunik (asymmetric volatility connectedness on the Forex market) should be noted among foreign scientists in foreign market research.

However, despite the current developments in the subject, the empirical (applied) aspects of technical analysis need to be further investigated in order to optimize their application in specific market situations.

The purpose of the article is to make a comparative analysis of the technical methods used by analysts in today's international currency market. The assignment of the article is to compare the individual tools of each method and determine the most effective among them.

Presentation of the main material and substantiation of the obtained research results. The period of creation of the international currency market with floating (not fixed) exchange rates was the 70s of the last century, known by the transition from Bretton Woods to the Jamaican currency system. The waiver of the gold exchange standard has greatly expanded the ability of states to determine the essence and principles of their own exchange rate policy, exchange rate regimes. At the same time, given the high volatility of the prices, especially in times of economic instability, preconditions for the expansion of speculative financial transactions, including in the international currency market, were created.

Predicting future currency price dynamics based on the history of their behavior emerged in the early 1990s. At the same time, the researchers proposed to distinguish 3 types of trends in prices changes:

— a «bullish» trend (exchange rate increases);

— a «bearish» trend (exchange rate decreases);

- a «flat» trend (the market is in the consolidation zone, fluctuations of the exchange rate are insignificant). [7, p. 123]

The basis of the technical analysis is built on 3 postulates that follow from the Dow's theory, developed by Charles Dow in 1900:

1) all possible factors are taken into account during pricing;

2) price movements are subject to trends;

3) the history develops in a spiral, therefore, it has the property of repeating itself. [8, p. 227]

In technical analysis, three methods are used to study the nature and patterns of price movements: graphical, mathematical approximation and theory of economic cycles. The graphical method emerged before others because of its ease of use and is capable of solving modeling problems on almost any time scale. The downside is the presence of a certain subjectivity, as an expert analyzes the already constructed chart.

Methods of mathematical approximation have become relevant along with the computer technology development, because they require large-scale mathematical calculations unlike the usual graphs. Their tasks are to filter out trend movements from non-trend ones.

The theory of economic cycles is used by experienced analysts to determine long-term price dynamics that can cover years. However, this method is much more complicated to use than the previous ones. In addition, the results often do not coincide with the real state of the market, since its mathematical conceptualization does not take into account a number of external factors.

The graphic analysis involves the study of the price graphs (charts), which are the basis for further forecasts of price dynamics. The most popular chart is "Japanese candlestick". Four indicators are used for its construction: the opening price, closing price, maximum and minimum prices for the period (Open, Close, Max and Min respectively). The coordinate system is rectangular (time is indicated on the horizontal axis, the price is indicated on the vertical axis). The example (see Figure 1) shows a weekly chart of the EUR / USD currency pair for the period 2018/10/01 - 2018/12/17.

A white candle (bullish candle) indicates that the closing price has exceeded the opening price, and a black (bearish candle) indicates the opposite. The last candle (bullish) on the chart as of 2018/12/17, as seen in Figure 1, has the following characteristics: Open - 1,1305; Close - 1,1359; Max - 1.1486; Min 1,13. Therefore, graphical analysis as exemplified by the «Japanese candlestick» helps the trader to see who currently holds the advantage in the market - «bulls» or «bears».

It should be noted that the price graph is a time series that allows you to use the methods of mathematical statistics and time series analysis. The main methods of time series analysis are spectral; correlation; neural networks; autoregressive and moving average models. In practice, when trading in the Forex market, the study of methods begins with a moving average, as it is further used as a component of more complex indicators. Moving average is a lagging indicator which smooths the price data and makes the current trend more visible. [4, p. 16] 


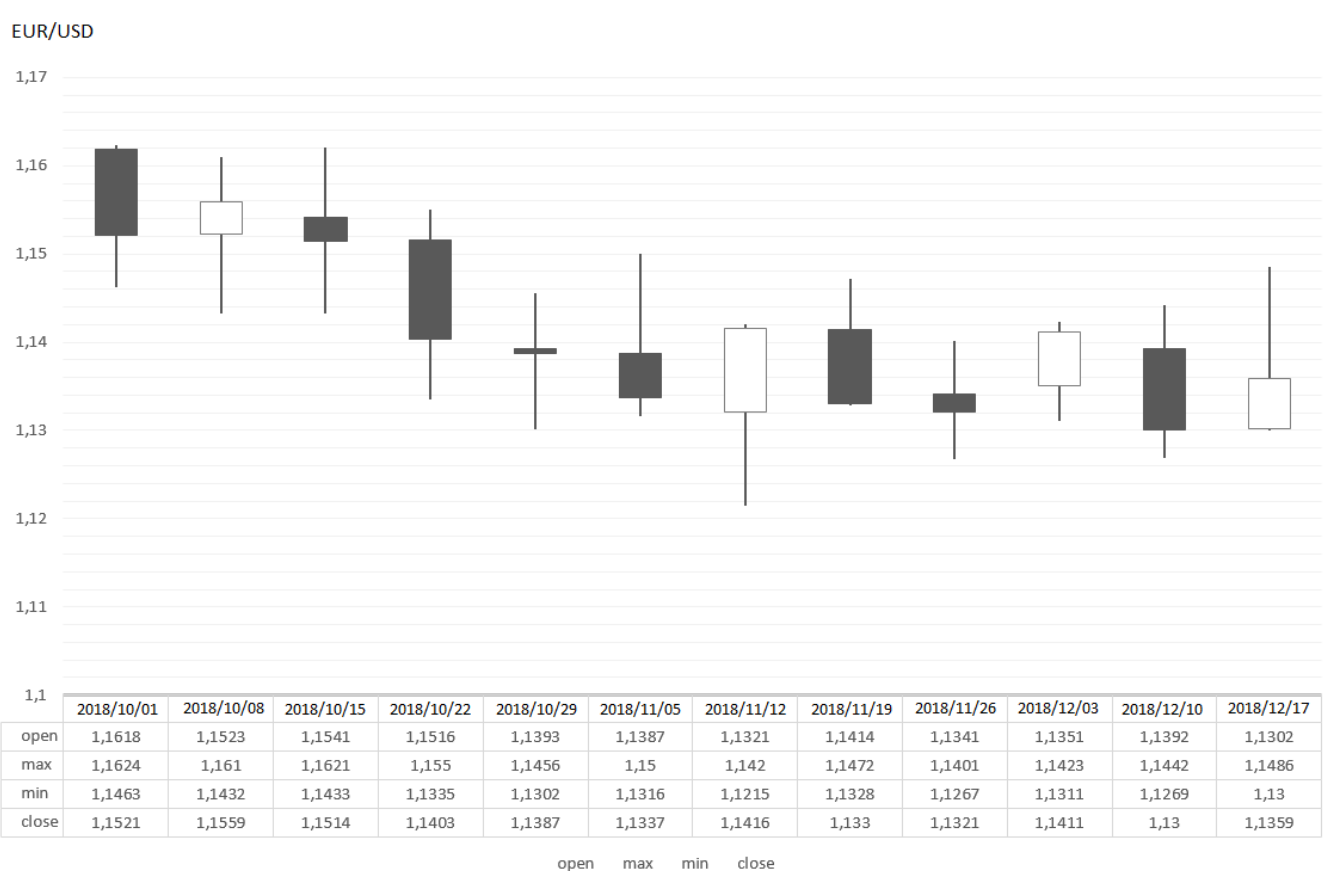

Fig. 1. The «Japanese Candlestick» chart for EUR/USD over a period of 2019/08/05 — 2019/11/18.

Source: compiled by the author according to the quotes values from the Forex Club website (https://www.fxclub.org).

Simple Moving Average is a moving average of the average prices for the selected period and is determined by the formula:

$$
\text { Simple Moving Average }=\frac{\sum_{i=1}^{n} P_{i}}{n}
$$

Where $P_{i}$ are market prices (usually the closing price is taken - Close);

$\mathrm{n}-$ is the smoothing length or the period of the moving average.

A weekly time chart with a period $\mathrm{n}=5$ can be used to construct a moving average curve. Using Formula 1, we calculate the moving average of prices for the last 5 weeks $\left(p_{n}-p_{n-5}\right)$ and add the value to the chart for the last week. Then we calculate the moving average for $p_{n-1}-p_{n-6}$ and enter the obtained value on the penultimate week, etc. The result is a curve (Figure 2):

The smaller the moving average parameter, the faster it detects a new trend, but produces more erroneous fluctuations. The larger the parameter, the slower the curve determines the new trend, but produces less erroneous fluctuations. The multiple curves can be plotted at a time for more accurate results in technical analysis. Description of the main moving average signals:

1) With a positive slope of the price curve, the reverse of the moving average curve from the bottom up is regarded as a buy signal. Conversely, with a negative slope of the price curve, the reverse of the moving average curve from top to bottom is a signal for sale.

2) The crossing of the long moving average and the short one from the bottom up is regarded as a signal to buy and vice versa.

3) The intervals of the greatest divergence of two moving averages are considered as a signal of a possible change of trend.

4) The slope of the moving average curve usually indicates the strength or speed of the trend. If the curve grows rapidly, the upward trend is strong. If the curve grows slowly, the upward trend is weak. The same analogy applies to the downward trend. 


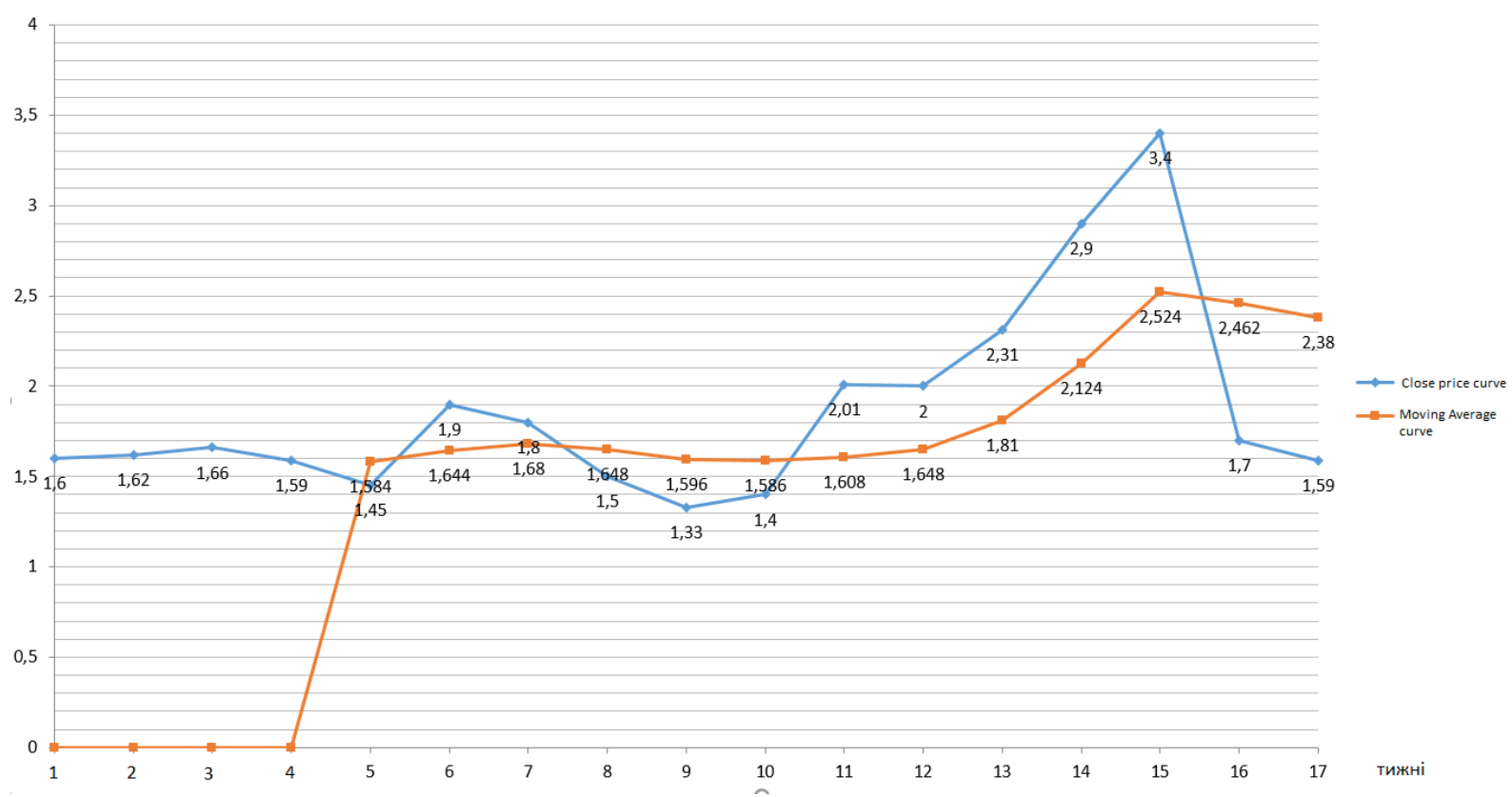

Fig. 2. An example of constructing a moving average curve.

Source: compiled by the author

5) Moving averages with round periods $(50,100,150$, etc.) are called moving support and resistance levels. The moving average convergence divergence (MACD) indicator is a momentum indicator that shows the relationship between two moving averages of price. [3, p. 20] Two curves (usually an exponential moving average) are used to plot the chart, with shorter and longer periods. Then a third average is used as a signal line to help determine when to buy and sell. [3, p. 20]

The exponential moving average is determined by the formula:

$$
\mathrm{EMA}=(\text { Close } \times \mathrm{P})+\mathrm{EMA}(\text { prev }) \times(1-\mathrm{P}))
$$

Close is the current period close price, EMA(prev) is the previous period's exponential moving average value and $\mathrm{P}$ is the percentage of using the close price value [4, c. 16].

There are two ways to plot a MACD: a linear MACD and a MACD histogram. To calculate the linear MACD, periods 12 and 26 are taken by default:

$$
\begin{gathered}
\text { MACD }=(\operatorname{EMAs}(12)-\operatorname{EMAI}(26)), \\
\text { Signal }=\operatorname{EMAa}(\operatorname{EMAs}(12)-\operatorname{EMAI}(26))=\operatorname{EMAa}(9) .
\end{gathered}
$$

where $\operatorname{EMAs}(12)$ is the exponential moving average with a short period;

$\operatorname{EMAl}(26)$ is an exponential moving average with a long period;

EMAa(9) is a smoothing exponential moving average with a short period identified by the difference between EMAs (12) and EMAl (26).

To construct a MACD histogram, it is necessary to remove the signal line (EMAa (9)) from the linear MACD. Usually, it is placed on a separate chart in the programs of technical analysis (Metatrader, Dealing Desk, Trade Station, Metastock). An example is shown in Figure 3.

The following is a description of the main MACD signals of the histogram:

If there is an upward trend in the Forex market and the slope of the histogram goes down, it means that the growth rate of the trend is gradually decreasing. Therefore, you need to look for points for sale.

If there is a downward trend and the histogram goes up, it means that the rate of the price descent is decreasing and you need to close the positions for sale.

The MACD histogram works in a proactive. Therefore, if the maximum values are reached as the histogram grows, then the next maximum price is likely to be higher than the previous one. Similarly, with the minimum.

Divergence allows fixing the main reverses and the beginning of a new trend. 


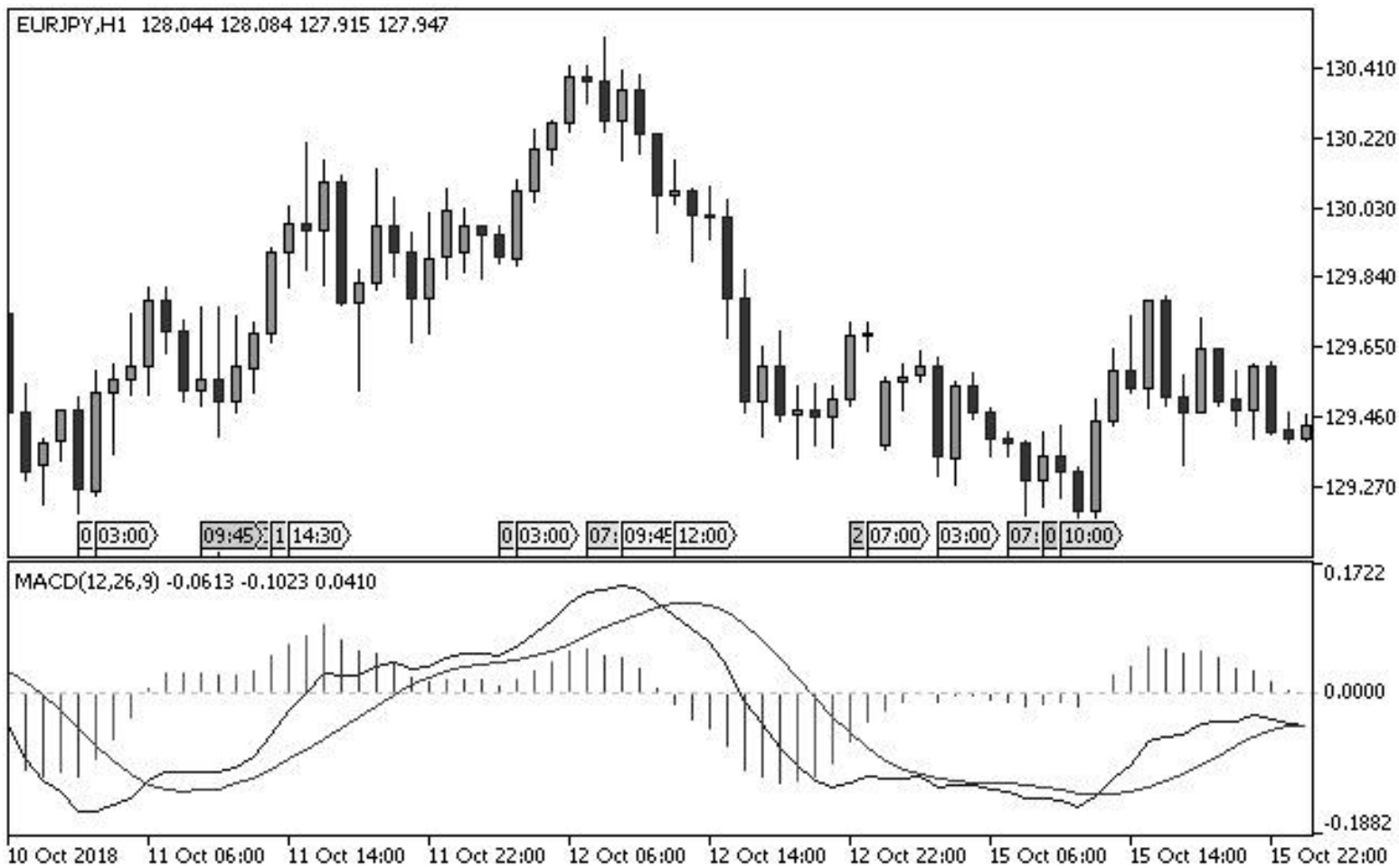

Fin. 3. An example of theMACD histogram.

Source: Super MACD Histogram, Metatrader 5

The main advantage of MACD histograms is the appearance of earlier signals than when using a single indicator. This is explained by the earlier manifestation of divergence on the histogram than the intersection of the moving averages. But the histogram is just a supplement to the indicator, and MACD shows the main reaction to the market. In addition, the disadvantage of MACD histograms is the filing of numerous erroneous signals in the flat (consolidation zone).

Unlike the graphical method and the mathematical approximation method, the theory of economic cycles for the analysis and forecasting of foreign exchange markets is applied mainly theoretically. In our opinion, its applied value should not be ignored, since this model is based on the third postulate of technical analysis which states about the cycle of history.

The wave theory of Ralph Nelson Elliott originated in the 30's of the last century. The foundations of this theory were the works by Charles Dow, William Hamilton and Edward Jones, the founders of the classical technical analysis. According to the theory, the movement of prices in the market is subject to the psychology of people and is a cyclical process of changing the impulse waves to the correction ones and vice versa. [6, p. 16] There are 8 waves in any price movement: 5 on-trend (impulse) and 3 against the trend (correction). In Fig. 4 waves 1,3,5 are impulse ones, as they determine the trend, and waves 2 and 4 are the corrective ones. In Figure 4 waves 1,3,5 are impulse, as they determine the trend, and waves 2 and 4 are the corrective ones. The corrective figure consists of three waves - A, B, C. In this case, A and C are impulse waves and B is a corrective wave. The Elliott sequence is a fractal, and each wave breaks down into smaller ones, preserving the structure. And the dependence of the links among themselves is determined by the Fibonacci levels, which became the mathematical basis of the theory. The number of Elliott waves coincides with the Fibonacci numbers. Fibonacci's ratios and correction lengths based on them are used to determine price targets. The ratio of the length of the correction to the previous movement of the market is often equal to $62 \%, 50 \%$, and $38 \%$. [1, p. 52] The classical wave ratio is as follows:

the 2 nd wave $-0.382,0.5$ or 0.618 of the 1 st wavelength;

the 3 rd wave $-1.618,0.618$ or 2.618 of the 1 st wavelength;

the 4 th wave -0.382 or 0.5 of the 1 st wavelength;

the 5 th wave $-0.382,0.5$ or 0,618 of the 1 st wavelength;

wave $\mathrm{A}-1,0.618$ or 0.5 of the 5 th wavelength;

wave $\mathrm{B}-0.382$ or 0.5 of the wavelength $\mathrm{A}$;

wave $\mathrm{C}-1.618,0.618$ or 0.5 of the wavelength A. [2, p. 121] 


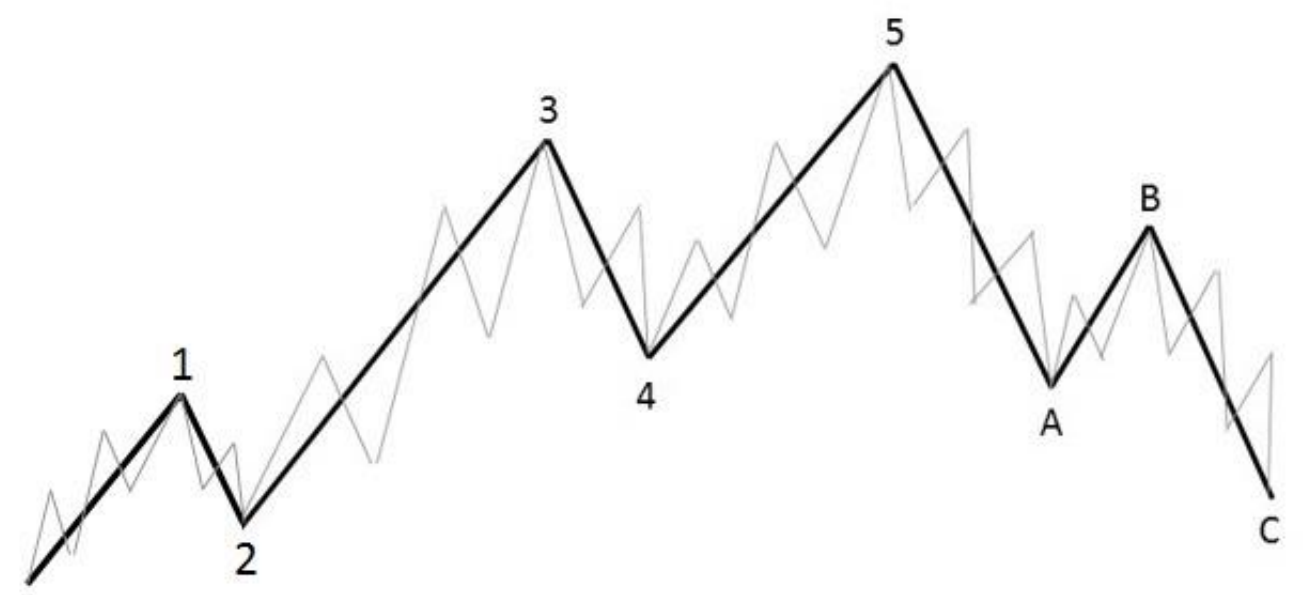

Fig. 4. An example of a complete Elliott wave cycle.

Source: created by the author

There are 3 basic rules for recognizing and plotting Elliott waves:

- wave 2 can in no case go beyond the level of wave 1 ;

- wave 3 can never be the shortest of a sequence. This is usually the wave with the strongest impulse;

- wave 4 never goes beyond the price territory of wave 1 .

A novice trader can use an auxiliary tool to plot Elliott waves, as finding extrema on the chart can be difficult. You can select indicators such as WATL (Wave AutoTrendLines), NeelyElliotWave, or Elliott Wave Prophet. An example is a ZigZag indicator (Figure 5), but its operation depends on the correct entry of the input parameters. Therefore, extremes are often found and waves are built manually. Basically, it is enough to use the "Japanese candlestick" or any other graphic tool for the layout of the waves. You can use the ATR (Average True Range) indicator to calculate the stop loss. Stop Loss is the automatic closing of a position when a price reaches a certain level. A set of these technical tools can be found in the Metatrader versions 4 and 5. The task of the trader is to determine the entry point (this is nothing but the end of the Elliott full wave cycle) and to choose the correct point to set the stop loss.

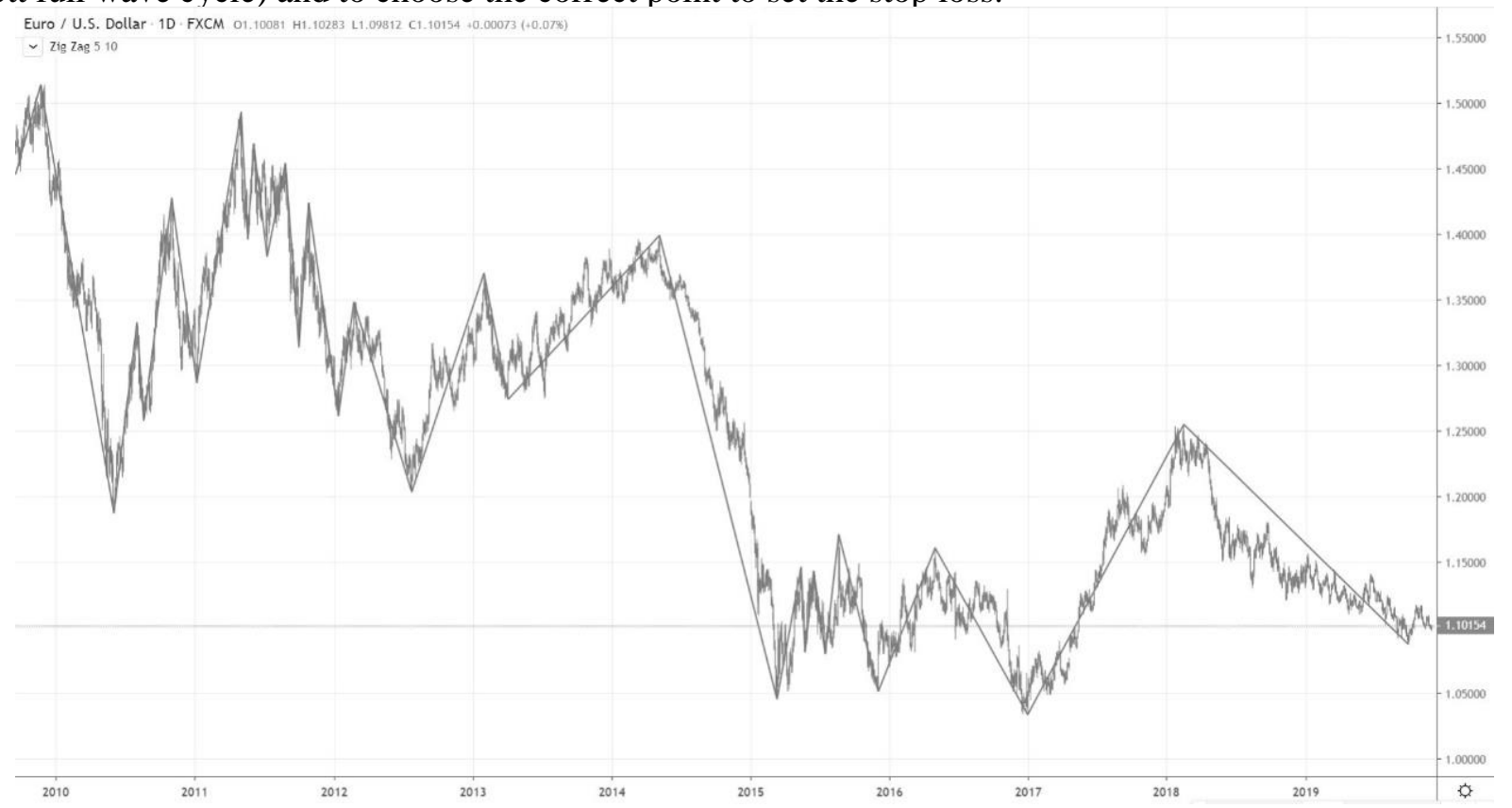

Fig. 5. Zigzag indicator (Elliott waves).

Source: TradingView platform (https://www.tradingview.com). 
Elliott wave theory classifies correction waves into 4 types of models:

— zigzag;

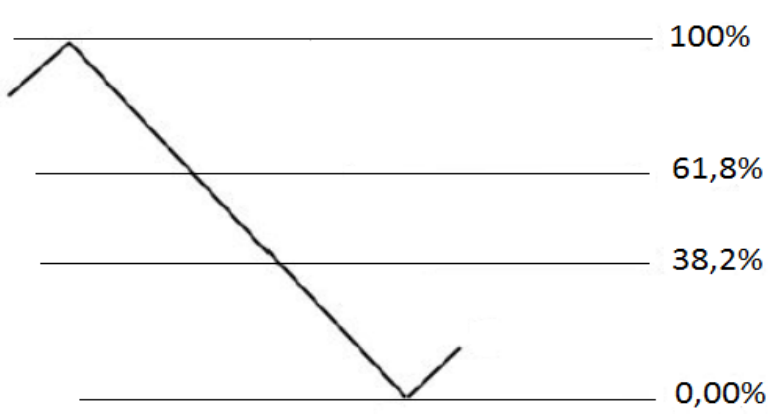

Fig. 6. «Bearish» trend

Source: created by the author

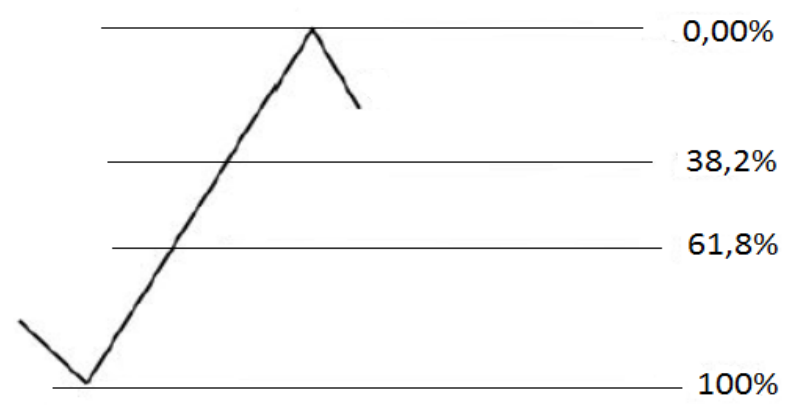

Fig. 7. «Bullish» trend.

Source: created by the author

- flat;

- triangle;

- combination.

Each model, in turn, has different variations, which makes them a difficult subject to study. It can take years to understand the theory and learn how to read real quotation charts. In general, the recommended step-by-step strategy for working with Elliott waves is the following:

1) determine the direction of the trend and be ready for the moment when the trend ends;

2) find the area where the appearance of correction is the most probable;

determine the correction model and its behavior; trend;

3) take advantage of additional technical analysis techniques to predict the point of completion of the

4) enter the position when the trend is expected to resume, taking into account the specific entry rules for each model.

Trading using the wave method is a difficult task as such, but when combined with other methods it is possible to get rid of the subjectivity of the Elliott waves. In the second step (search of the correction) you can run the built-in tool in the Metatrader - Fibonacci Extension. It is important not to make a mistake by selecting the Fibonacci levels that are used when the impulse is over (wave 5) and the correction begins. The Fibonacci extension is built when none but the first impulse has passed (wave 1). In the last step (opening the position) it is advisable to activate the MACD histogram, which has been already described above. In this case, its purpose is to detect a slowdown in an impulse when the price reaches the price zone where trading can begin from. You can also strengthen by using the third tool - the Fibonacci levels.

The Fibonacci levels are the percentage ratios of the Fibonacci coefficients. Only a few levels are important for practical application:

- Fibonacci corrective levels: 11,8\%; 23,6\%; 38,2\%; 50,0\%; 61,8\%; 76,4\%; 88,2\%.

- Fibonacci impulse levels: $123,6 \% ; 138,2 \% ; 161,8 \% ; 200,0 \% ; 238,2 \% ; 261,8 \% ; 300,0 \% ; 338,2 \%$; 400,0\%; 423,6\%. [5, p. 41].

Fibonacci levels allow identifying possible correction goals, as well as strong levels of resistance and support. Typically, this tool is already built into trading platforms. It is also in the Metatrader technical arsenal. In practice, it becomes apparent that no trend can continue indefinitely, and sooner or later the correction occurs. Therefore, the main levels are corrective levels: $38.2 \%, 50.0 \%$ and $61.8 \%$ (Figures 6; 7).

These levels have the greatest resistance and support when changing course. Most often, on the basis of practical research, it is found that the price is adjusted by $38.2 \%$. [5, p. 41] If you combine the Elliott waves, the moving average and the Fibonacci levels, the most likely reverse of the curve and the beginning of a new trend will be observed at $38.2 \%$. By activating this tool, you can track the change in exchange rates, which lies in the range of values specified by the Fibonacci ratios. 
The subjectivity of Elliott's wave theory is that any two analysts who apply this technique in the same market often get different results. However, this theory may become more powerful in predicting currency fluctuations in symbiosis with another element of technical instrumentation. The main difference between the three methods of technical analysis in the complexity of use, i.e. in the application of mathematical computing and computer technology. The choice of any of them depends on the experience and the level of knowledge of the trader. Also, each method is different in strategy (short or long term). Common features of the graphical method, mathematical approximation and theory of economic cycles are the purpose of analysis, the object of analysis and influence of the «psychology of people» factor.

Conclusions and prospects for further research. Technical analysis methods are different and allow the use of a wide range of tools. Each trader can choose the tool that will be most convenient for him.

It is most advantageous to combine several technical tools at the same time. Knowing the weaknesses and strengths of different instruments, you can choose the ones that will confirm each other's signals. This combination will allow you to make the right decisions when trading in the foreign exchange market and maximize profit of traders. The prospect of further research is about finding the best strategic schemes using a broad spectrum of technical analysis tools of the international currency market.

\section{Джерела та література}

1. Афенкина Е. М. Применение теории волн Эллиота при анализе индекса РТС. Новый университет. Сер. «Экономика и право»: «Коллоквиум», 2015. Вып. 6(52). С. 52-55.

2. Куличкина И. И. Волновая теория Эллиота как метод технического анализа. Новые информационные технологии в науке : сб. ст. межд. науч.-практ. конф. Уфа : МЦИИ ОМЕГА САЙНС, 2017. ВЫП. 3. Ч. 1. С. 120122.

3. Min, A. K., Barefoot, J. E., \& Cullen, M. R. Currency Trading System Development. 2019. 125 p. URL: https://digitalcommons.wpi.edu/iqp-all/5402 (retrieved: 30.11.2019).

4. M Ozturk, IH Toroslu, G Fidanю. Heuristic based trading system on Forex data using technical indicator rules: thesis for the master degree: the graduate school of natural and applied sciences of middle east technical university, 2015. $115 \mathrm{p}$.

5. Пушкин А. А. Особенности построения и применения линий тренда, горизонтальных уровней, каналов, уровней Фибоначчи в биржевой торговле. Актуальные проблемы современной науки : сб. тез. науч. ст. науч.-практ. конф. Санкт-Петербург-Астана-Киев-Вена : «Интернаука», 2019. С. 35-44.

6. Слюсар А. В. Система прийняття рішень на основі вейвлетної ідентифікації хвиль Елліота : магістерська дис. : 124 Системний аналіз / Слюсар Андрій Вячеславович. Київ, 2018. 72 с.

7. Шабдыраимов П. А. Анализ и его роль для выстраивания стратегии поведения на валютном рынке. Развитие науки и техники: механизм выбора и реализация приоритетов: сб. ст. межд. науч.-практ. конф. Омск : «АЭТЕРНА», 2017. ВЫп. 6. Ч.2. С. 122124.

8. Щитова А. С. Анализ методов прогнозирования валютного рынка. Проблемы и перспективы экономических отношений в постиндустриальном обществе: сб. ст. межд. науч.-практ. конф. Самара : «АЭТЕРНА», 2017. ВЫп. 2. Ч.2. С. 226-230.

\section{References}

1. Afenkina E. M. (2015). Primenenie teorii voln Ellyota pri analize indeksa RTS [Application of the Elliott Wave Theory in the Analysis of the RTS Index]. Novyy universitet. Ser. «Ekonomika i pravo». 6(52), (pp. 52-55). Kollokvium [in Russian].

2. Kulichkina I. I. (2017). Volnovaya teoryia Ellyota kak metod tekhnicheskoho analiza [Elliott Wave Theory as a Method of Technical Analysis]. Novye informatsionnye tekhnologii v nauke: sb. st. mezhd. nauch.-prakt. konf. Ufa: MTsII OMEHA SAYNS. Vyp.3 (1), (pp. 120-122) [in Russian].

3. Min, A. K., Barefoot, J. E. D., \& Cullen, M. R. (2019). Currency Trading System Development. Retrieved November 30, 2019, from https://digitalcommons.wpi.edu/iqp-all/5402.

4. M. Öztürk, IH Toroslu, G Fidanю. (2015). Heuristic based trading system on Forex data using technical indicator rules: thesis for the master degree: the graduate school of natural and applied sciences of middle east technical university [in English].

5. Pushkin A. A. (2019). Osobennosti postroeniya i primeneniya liniy trenda, gorizontalnykh urovney, kanalov, urovney Fibonachchi v birzhevoy torgovle [Features of the Construction and Application of Trend Lines, Horizontal 
Levels, Channels, Fibonacci Levels in Exchange Trading]. Aktualnye problemy sovremennoy nauki: sb. tez. nauch. st. nauch.-prakt. konf. - Sankt-Peterburh-Astana-Kyev-Vena: ,Internauka”, (pp. 35-44) [in Russian].

6. Sliusar A. V. (2018). Systema pryiniattia rishen na osnovi veivletnoi identyfikatsii khvyl Elliota [Decision Making System Based on Elliott Wavelet Wave Identification]. Mahisterska dys.: 124 Systemnyi analiz - Sliusar Andrii Viacheslavovych - Kyiv [in Ukrainian].

7. Shabdyraimov P. A. (2017). Analiz i ego rol dlia vystraivaniya strategii povedeniya na valyutnom rynke [Analysis and Its Role for Building a Strategy of Behavior in the Foreign Exchange Market]. Razvitie nauki i tekhniki: mekhanizm vybora i realizatsiya prioritetov: sb. st. mezhd. nauch.-prakt. konf. 6(2), (pp. 122—124) — Omsk — "AETERNA" [in Russian].

8. Shchitova A. S. (2017). Analiz metodov prognozirovaniya valyutnogo rynka [Analysis of Methods for Forecasting the Foreign Exchange Market].Problemy i perspektivy ekonomycheskikh otnosheniy v postindustrialnom obshchestve: sb. st. mezhd. nauch.-prakt. konf. 2(2), (pp. 226-230) — Samara — “AETERNA” [in Russian].

Стаття надійшла до редакції 24.12.2019 р. 